\title{
LOCALIZATION OF ACID PHOSPHATASE ACTIVITY IN THE APOPLAST OF ROOT NODULES OF PEA (PISUM SATIVUM)
}

\author{
MARZENA SuJKowsKa, WoJCIECH BORUCKI, WŁADYSŁAW GOLINOWSKI \\ Faculty of Agriculture and Biology, \\ Department of Botany, Warsaw Agricultural University \\ Nowoursynowska 159, 02-776 Warszawa, Poland \\ e-mail: Sujkowska@delta.sggw.waw.pl
}

(Received: June 3, 2005. Accepted: October 17, 2005)

\begin{abstract}
Changes in the activity of acid phosphatase (AcPase) in the apoplast of pea root nodule were investigated. The activity was determined using lead and cerium methods. The results indicated a following sequence of AcPase activity appearance during the development of the infection thread: 1) low AcPase activity appears in the outer part of cells of symbiotic bacteria; 2) bacteria show increased AcPase activity, and the enzyme activity appears in the thread walls; 3) activity exhibits also matrix of the infection thread; 4) bacteria just before their release from the infection threads show high AcPase activity; 5) AcPase activity ceases after bacteria transformation into bacteroids. The increase in bacterial AcPase activity may reflect a higher demand for inorganic phosphorus necessary for propagation of the bacteria within the infection threads and/or involved in bacteria release from the infection threads.
\end{abstract}

KEY WORDS: acid phosphatase, localization, infection thread, nodule, Pisum sativum.

\section{INTRODUCTION}

Symbiotic interaction between plants and rhizobia is almost completely restricted to leguminous plants and results in the formation of a new organ, the root nodule. In the nodules, bacteria are hosted extracellularly in the infection threads and intracellularly where they find ideal environment to reduce atmospheric nitrogen into ammonia that is next assimilated by the plant (Mylona et al. 1995). Several stages are recognized in the nodulation process. An important event within the curled root hair is the formation of the infection thread, which contains bacteria and penetrates the root hair. Subsequently, the infection thread grows and branches into the root inner cortex where the nodule primordium is formed. From enlarged infection-thread tips, bacteria are released into cytoplasm of the nodule primordium (Basset et al. 1977). Within the host cytoplasm the bacteria are surrounded by a host membrane; they form the so-called symbiosome. In the symbiosomes, the bacteria develop into bacteroids, which are morphologically distinct from free-living bacteria (Vasse et al. 1990), able to fix atmospheric nitrogen.

In the plant tissues the apoplast is mainly composed of plant cell walls and intercellular spaces. In the root nodules there is an additional apoplast zone, which is represented by infection threads present in the penetration zone, early symbiosis zone and nitrogen fixation zone (Higashi et al. 1986). The synthesis and composition of the infection threads are thought to be similar to that of the host cell wall; inside them bacteria become embedded in plant cell wall- like matrix (Newcomb and McIntyre 1981). Specific plant glycoproteins and other proteins are present in the infection threads. Some nodulins (nodule-specific plant proteins) are probably directed to the infection thread matrix (Buchanan et al. 2000).

During growth and extension of infection thread bacteria propagate within them. Bacteria propagation and the growth of infection thread are a highly coordinated processes. Phosphorus partitioning between the plant cell and bacteria (bacteroids) is of extreme importance for root nodule functioning and it may control bacteria propagation within infection threads. Also, hydrolysis of phosphate esters catalyzed by phosphatases is a critical process in the energy metabolism and metabolic regulation of plant cell (Duff et al. 1994).

AcPases are ubiquitous non-specific enzymes, that share the ability to hydrolyse various phosphate esters with the release of phosphate ions (Tu et al. 1990). Phosphatase activity is well-described for animal and plant tissues as well as microorganisms (Aoyama et al. 2001). Particularly, plant acid phosphatases have been detected in roots (Penheiter et al. 1997), tubers (Gellaty et al. 1994), bulbs (Guo and Pesacreta 1997), seeds (Ullah and Gibson 1988), aleurone layers (Gabard and Jones 1986), leaves (Staswick et al. 1994), scutellum (Rossi et al. 1981), root nodules (Penheiter et al. 1997) and suspension cells cultures (Lefebvre et al. 1990; Duff et al. 1989). Acid phosphatases (or acid phosphatase activity) have been localized in many cellular compartments including cell walls, vacuoles, membranes, Golgi complex, chloroplasts and cytoplasm (Panara et al. 1990; 
Duff et al. 1994; Olmos and Hellin 1997). They were also detected in the symbiosome membrane of soybean root nodules (Penheiter et al. 1997). The diversity and ubiquity of plant AcPases together make a consensus on their precise physiological role(s) difficult to achieve (Duff et al. 1994). They are believed to be involved in the release, transport and recycling of Pi (Bozzo et al. 2002). Several roles have been ascribed to AcPases in plants, i.e. participation in signal transduction (Plaxton and Carswell 1996), involvement in plant's response to salt stress (Pan 1987), water deficit (Barret-Lennard et al. 1984), wounding (Jones and Villiers 1972) and the hypersensitive response (HR) (Kenton et al. 1999). However, a comprehensive understanding of the metabolic function of acid phosphatases is lacking, partly due to large number of phosphatases, as well as their general lack of substrate specificity (Duff et al. 1991).

In this paper, localization of acid phosphatase activity in pea (Pisum sativum) root nodules have been examined in order to characterize the root nodule apoplast. This is the first cytochemical localization of AcPase activity during the development of infection threads within the root nodule.

\section{MATERIAL AND METHODS}

\section{Plant material}

Pea seeds (Pisum sativum cv. Sześciotygodniowy) were sterilized with calcium hypochlorite, rinsed in distilled water and germinated for three days at room temperature. Seedlings with roots ca. $2 \mathrm{~cm}$ long were transferred to pots (five plants per pot) filled with sterile perlite and inoculated with Rhizobium leguminosarum bv. viciae 248 (wild type, effective). For 72 hours the bacteria cultured at room temperature on liquid medium at $\mathrm{pH}=7$, which contained in 1 liter: $0.5 \mathrm{~g} \mathrm{~K}_{2} \mathrm{HPO}_{4}, 0.3 \mathrm{~g} \mathrm{MgSO}_{4}, 0.1 \mathrm{~g} \mathrm{NaCl}, 10 \mathrm{~g}$ saccharose and $0.5 \mathrm{~g}$ yeast extract, shaking all the time. Inoculum comprised $20 \mathrm{ml}$ of the bacterial suspension per pot. The plants were grown under controlled conditions: day $16 \mathrm{~h}, 20-22^{\circ} \mathrm{C}$, night $8 \mathrm{~h}, 14-16^{\circ} \mathrm{C}$. The plants were illuminated with sodium lamp lighting (600 mE/m2/s PAR) and watered with nitrogen-free nutrient solution (Fahraeus 1957). Eighteen days after inoculation of pea seedlings with Rhizobium longitudinal hand sections of pea root nodules (ten from each plant) were collected and fixed.

\section{Localization of acid phosphatase activity}

- light microscopy (LM)

Acid phosphatase activity was localized using the modified Gomori technique (Gomori 1950). Hand sections of nodules were fixed in $4 \%$ paraformaldehyde in $0.05 \mathrm{M}$ cacodylate buffer, $\mathrm{pH} 7.2$, at $0^{\circ} \mathrm{C}$ for $2 \mathrm{hrs}$, washed with 0.05 $\mathrm{M}$ cacodylate buffer for $1 \mathrm{~h}$ in an ice bath. Material was preincubated in $0.1 \mathrm{M}$ acetate buffer $\mathrm{pH} 5.0$ with $1 \mathrm{mM} \mathrm{Pb}$ $\left(\mathrm{NO}_{3}\right)_{2}$, for $1 \mathrm{~h}$ at $37^{\circ} \mathrm{C}$, and then incubated in the reaction medium composed of: $0.5 \mathrm{mM} \beta$-glycerophosphate, $1 \mathrm{mM}$ $\mathrm{Pb}\left(\mathrm{NO}_{3}\right)_{2}$ in $0.1 \mathrm{M}$ acetate buffer, $\mathrm{pH} 5.0$ for $30 \mathrm{~min}$ at $37^{\circ} \mathrm{C}$. Control treatments involved: i) incubation in the medium without substrate, ii) incubation in the presence of substrate and AcPase inhibitors: $10 \mathrm{mM} \mathrm{NaF}$ or $\mathrm{ZnCl}_{2}$, iii) AcPase inactivation at $80^{\circ} \mathrm{C}$. The first rinse after incubation was in the preincubation medium $(15 \mathrm{~min})$, followed by three washes with acetate buffer. The lead phosphate precipitates were made visible under a light microscope by their conversion to lead sulphide using $0.01 \%\left(\mathrm{NH}_{4}\right)_{2} \mathrm{~S}$ for 20 minutes.

\section{Localization of acid phosphatase activity \\ - transmission electron microscopy (TEM)}

Acid phosphatase activity was localized using the cerium-based procedure of Record and Griffing (1988). Thin sections of nodules were fixed in $2.5 \%(\mathrm{v} / \mathrm{v})$ glutaraldehyde in $0.1 \mathrm{M}$ cacodylate buffer, $\mathrm{pH} 7.2$, at $0^{\circ} \mathrm{C}$ for $2 \mathrm{hrs}$, and washed with $0.1 \mathrm{M}$ cacodylate buffer for $1 \mathrm{~h}$ in an ice bath. Material was preincubated in $0,1 \mathrm{M}$ acetate buffer $\mathrm{pH} 5.0$ containing $1 \mathrm{mM} \mathrm{CeCl}_{3}$, for $1 \mathrm{~h}$ at $37^{\circ} \mathrm{C}$, then incubated at $37^{\circ} \mathrm{C}$ in a reaction medium $(0.5 \mathrm{mM} \beta$-glycerophosphate, 1 $\mathrm{mM} \mathrm{CeCl}_{3}$ in $0.1 \mathrm{M}$ acetate buffer, $\mathrm{pH}$ 5.0) for $30 \mathrm{~min}$. Tissue was postfixed with $1 \% \mathrm{OsO}_{4}$ for $3 \mathrm{hrs}$, dehydrated in a graded alcohol series and embedded in glycid ether 100 epoxy resin (SERVA). Ultrathin sections were stained with uranyl acetate followed by lead citrate (Reynolds 1963) for 1 min and examined under TEM (JEM1220, JEOL, Japan).

\section{RESULTS}

\section{Anatomy of pea root nodule}

Pea root nodules are cylindrical and have apical meristem at their distal end. Nodule meristematic cells differentiate into cortical or bacteroid tissue cells. Vascular bundles are embedded in cortical cells. The bacteroid tissue exhibited zonation such as: (Fig. 1A and B) infection thread penetration zone, where bacteria are released from the infection threads to the plant cells (I), young bacteroid tissue zone (II), interzone with large amyloplasts (I/II) and mature bacteroid tissue zone (III). The mature zone was pink-colored due to the presence of leghemoglobin and is the site of symbiotic nitrogen fixation. Old pea nodules contained also a senescent zone, which was green-colored resulting from degradation of leghemoglobin (not shown).

\section{Localization of acid phosphatase activity - LM}

The activity of AcPase was much higher in infection threads than in the adjacent plant cell walls (Fig. 1C). Enzyme activity was detected in all infection threads, independently of their location in bacteroid tissue. Using $1 \mathrm{mM} \mathrm{Pb}\left(\mathrm{NO}_{3}\right)_{2}$ for Pi detection, we did not get any nuclear staining (Fig. 1C).

In the present study, $\mathrm{Zn}^{2+}, \mathrm{F}^{-}$and high temperature were used for inhibition of AcPase activity within the nodule. No precipitation of lead sulfide were visible in infection threads or other areas in controls without the substrate (Fig. 1D) or with sodium fluoride or zinc chloride, which inhibit AcPase activity (Fig. 1E). The AcPase activity was inhibited completely by fluoride (Fig. 1E) and high temperature (data not shown).

\section{Localization of acid phosphatase activity - TEM}

Low acid phosphatase activity visualized with black precipitates was detected in the outer parts of bacteria enclosed in young infection threads developing close to the nodule meristem (Fig. 2A). Bacteria of the older infection threads, found in differentiating plant cells of the petentration zone of infection thread, showed higher AcPase activity concomitantly with appearance of activity in cell walls and matrix of the threads. Electron-transparent discontinuities (crevice-like) with very high acid phosphatase activity 

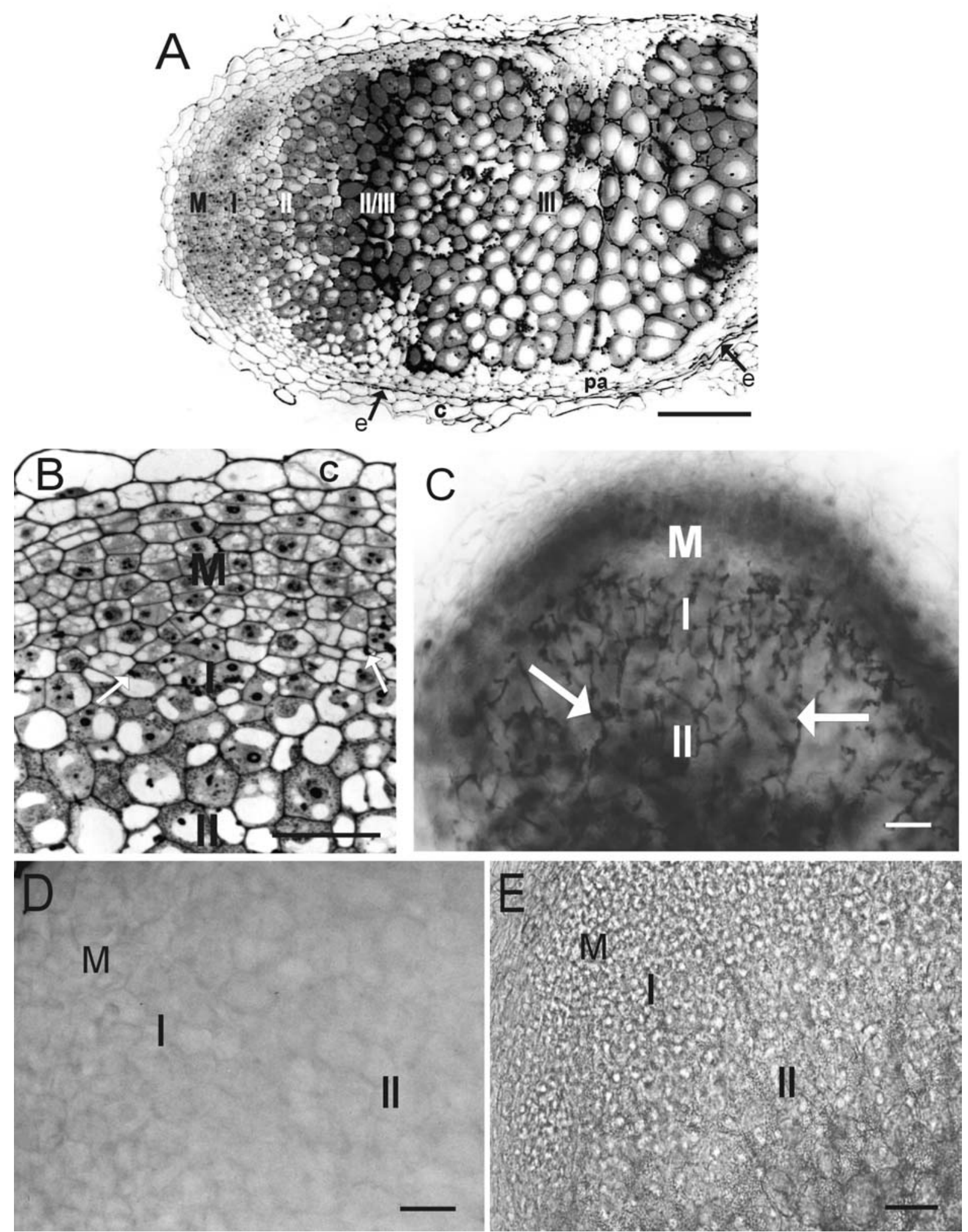

Fig. 1. (A) Anatomy of the pea root nodule, longitudinal section. Visible distinct zonation of the bacteroidal tissue. M - meristem; bacteroid tissue composed of: I - infection thread penetration zone, II - early symbiosis zone, II/III - interzone with large amyloplasts, III - nitrogen fixing zone. pa parenchyma; $\mathrm{e}$ - nodule endodermis; c - nodule cortex. Bar $=200 \mu \mathrm{m}$. (B) Apical part of pea root nodule, longitudinal section. Bar $=50 \mu \mathrm{m}$. $(\mathbf{C})$ Distribution of the infection threads in the apical part of the pea root nodule. Black deposits of lead sulfide at the infection threads (arrows) indicate AcPase activity. Bar $=400 \mu \mathrm{m}$. (D) Control. The plant material incubated without substrate $(\beta$-glycerophosphate). Bar $=200 \mu \mathrm{m}$. (E) Control. The pea root nodule incubated with phosphatase inhibitor ( $10 \mathrm{mM} \mathrm{NaF}$ ). No deposits of lead sulfide are visible. Bar $=200 \mu \mathrm{m}$.

around them were often visible within infection thread matrix (Fig. 2B and C). In the last stage of development of the infection thread, the bacteria are released from unwalled thread tips and are endocytotically internalized by the host cell called "infected cells". Just before bacteria were relea- sed, they showed enhanced acid phosphatase activity (Fig. 2D). After bacteria were released from the infection threads the enzyme activity ceased (Fig. 2D). Controls without substrate (Fig. 2E and F) did not show any precipitates in the infection threads or any other structures. 

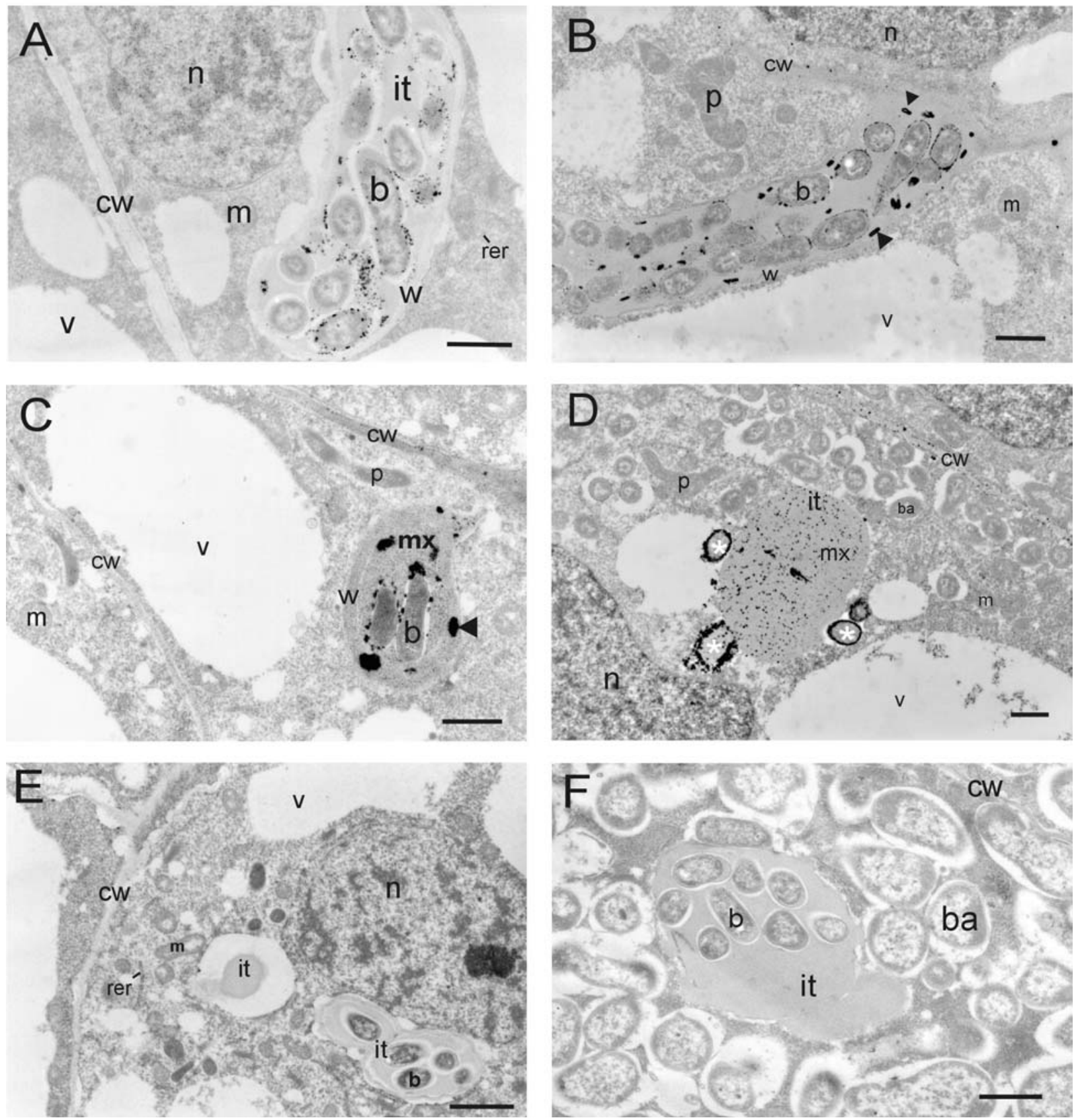

Fig. 2. Subcellular localization of AcPase activity in pea root nodule. $\mathrm{b}$ - bacteria; ba - bacteroids; $\mathrm{cw}$ - plant cell wall; it - infection thread; $\mathrm{m}$ - mitochondrion; $\mathrm{mx}$ - infection thread matrix; $\mathrm{n}$ - nucleus; $\mathrm{p}$ - plastid; rer - endoplasmatic reticulum; $\mathrm{w}-$ infection thread wall; $\mathrm{v}-\mathrm{vacuole}$. Bar $=1 \mu \mathrm{m}$. $(\mathbf{A})$ Meristematic part of pea root nodule. Black precipitates of cerium phosphate show location of AcPase activity in the outher parts of bacteria enclosed within infection thread. (B) Infection thread penetration zone. Reaction product at the plant cell wall, in the outer parts of bacteria, in the infection thread walls, high AcPase activity show discontinuities within thread matrix (arrowheads). (C) AcPase activity within the infection thread matrix and plant cell walls. (D) Early symbiosis zone. Bacteria just before their release (asterix) from the infection thread show distinct AcPase activity, but bacteroids exibit only low AcPase activity. Reaction product also appears in the infection thread matrix and at the plant cell wall. (E) Control without substrate. Infection thread (it) in the meristematic part of the nodule. No cerium precipitates are visible. (F) Control without substrate. Early symbiosis zone. Bacteria are released from the infection thread to the cytoplasm of infected cell. Lack of AcPase activity within infection thread as well as around bacteroids.

\section{DISCUSSION}

\section{Evaluation of methods of AcPase activity localization}

The most commonly used cytochemical method for localization of acid phosphatase activity is Pi capture. The investigation of the subcellular distribution of acid phosphatase activity in pea nodules by the technique of Gomori (1950) indicates that AcPase activity is localized mainly in the infection threads (Fig. 1C). However, the lead technique has been criticized by several authors (Kantz et al.
1988; Chauhan et al. 1991), because it may produce nonspecific precipitates and because some enzymes can be sensitive to lead. Nevertheless, the technique has been widely used in plant and animal cytochemistry (Hall et al. 1992). Based on the above reports, low lead concentration [1 mM Pb $\left.\left(\mathrm{NO}_{3}\right)_{2}\right]$ was used in this work, which did not cause non-specific staining of nucleus or non-specific reactions in the medium without the substrate (Fig. 1D). Recently, cerium-based methods have been extensively used in the ultrastructural localization of several phosphatases in 
animal (Hulstaer et al. 1983) and plant tissues (Record and Griffing 1988; Hall et al. 1992; Olmos and Hellin 1997). Cerium cations react directly with inorganic phosphate forming insoluble electron-dense precipitates detectable by TEM (Olmos and Hellin 1997). The cerium concentration used in this research $(1 \mathrm{mM})$ did not result in non-specifically located precipitates (Fig. 2E and F).

\section{Acid phosphatase localization in pea nodules}

Acid phosphatase activity appeared to be regulated by the level of inorganic phosphate in the environment however the mechanisms, which regulate enzyme distribution and activity, are unclear (Tu et al. 1990). Developmental processes that cause AcPase induction include seed germination (Gibson and Ullah 1988), flowering and senescence (De Leo and Sacher 1970; Lal and Jaiswal 1988), greening of etiolated seedlings (Christeller and Tolbert 1978) and fruit ripening (Kanellis et al. 1989). Environmental factors that elicit increased expression of AcPases include: salt stress (Pan 1987), water deficit (Barret-Lennard et al. 1984), phosphorus starvation (Lefebvre et al. 1990), wounding (Jones and Villiers 1972), hypersensitive response (HR) (Kenton et al. 1999).

Sodium fluoride or zinc chloride inhibited AcPase activity in apoplast of pea root nodules (Fig. 1E). Complete inhibition of AcPase activity by fluoride (Fig. 1E) and high temperature (data not shown) were observed. Competitive inhibition by $\mathrm{Pi}$ and uncompetitive inhibition by fluoride have been observed by other authors (Randall and Tolbert 1971; Duff and others 1989). Molybdate and fluoride (Duff et al. 1989) are strong APase inhibitors. Potent competitive inhibition of plant AcPases by arsenate, ascorbate, zinc and vanadate was reported (Randall and Tolbert 1971; Duff et al. 1991; Ferreira et al. 1999).

Numerous rhizobia are similar to other Gram-negative bacteria (Torriani 1990) in that phosphorus stress induces phosphatases and leads to significantly increased phosphorus transport rates (Smart et al. 1984). Phosphorus partitioning between plant cell and bacteria (bacteroids) can be of extreme importance for root nodule functioning. Bacteria (bacteroids) probably compete for Pi with (host) plant cells. In the present study, in the early stage of development of infection thread, we localized the AcPase activity around bacteria within the infection threads (Fig. 2A and B), which suggests that bacteria produce this enzyme. We suppose that bacteria inside the infection threads can be under phosphorus deficiency stress, because the only way to obtain phosphorus is to get it from the host plant. Interestingly, after bacteria leave the threads and transform into bacteroids, their AcPase activity gradually ceases (Fig. 2D). These results suggest that functioning of the bacteroids of pea root nodule is not dependent on AcPase activity. We speculate that Pi may be one of the factors controling bacteria propagation within the infection threads. On the other hand, lack of AcPase activity in pea bacteroids may inhibit phosphorus recycling and lead to their senescence. The lack of AcPase activity in bacteroids may reflect no limitation in phosphorus delivery to the symbiosomes from plant cells. It is possible that bacteroids produce AcPase isoforms sensitive to the fixation and processing of plant material or may to share the activity of alkaline phosphatase (AlPase).

Biochemical investigations of Penheiter et al. (1997) revealed that AcPase is localized in the symbiosome mem- brane of soybean root nodules. The authors suggested that this enzyme is important for efficient nodule metabolism. AcPase was also reported in the peribacteroid space of soybean nodules (Bassarab and Werner 1989). Both, peribacteroid membrane and peribacteroid space of pea bacteroids did not exhibit AcPase activity (Fig. 2D). This can result from a possible sensitivity of some bacterial isomers of AcPase to glutaraldehyde fixation and processing of the material. Our results suggest that bacterial AcPase activity gradually increases and reaches the maximum just before bacteria release from the infection thread. It is possible that the Pi requirement is rather low in bacteria located in fully walled parts of infection threads. Intensive bacteria propagation, accompanied by the enlargement of infection thread tips, may be responsible for higher Pi request expressed by higher AcPase activity. On the other hand, the maximum of AcPase activity in bacteria just before and during their release from infection threads strongly suggests that the activity may be helpful in the process of plant cell infection. According to our knowledge, there are no reports on the role of AcPases in modification of properties of plant cell wall and/or the components of the infection thread. The increase in AcPase activity of bacteria origin during the development of the infection thread may also reflect a high request for inorganic phosphorus, necessary for bacteria propagation.

We speculate that crevice-like structures can be formed as a result of tension, which rises during growth of the infection threads. The diffusion of $\beta$-glycerophosphate is probably much faster in these places, which can result in higher AcPase activity around them.

Further histochemical and biochemical investigations of AcPase activity in pea nodules and originated from different plant species are needed to solve the role of AcPase activity in development of infection threads and bacteroid functioning.

\section{ACKNOWLEDGEMENTS}

We thank Ewa Znojek, Maria Gromadka for expert technical assistance.

\section{LITERATURE CITED}

AOYAMA H., CAVAGIS D.M., TAGA E.M., FERREIRA C.V. 2001. Endogenous lectin as possible regulator of the hydrolysis of physiological substrates by soybean seed acid phosphatase. Phytochem. 58: 221-225.

BARRET-LENNARD E.G., ROBSON A.D., GREENWAY H. 1984. Effects of phosphorus deficiency and water deficit on phosphatase activities from wheat leaves. J. Exp. Bot. 33: 682-693.

BASSARAB C.A., WERNER D. 1989. $\mathrm{Mg}^{2+}$-dependent pyrophosphatase, a tonoplast enzyme in the peribacteroid membrane of Glycine max root nodule. Symbiosis 7: 81-94.

BASSET B., GOODMAN R.N., NOVACKY A. 1977. Ultrastructure of soybean nodules. I: release of rhizobia from the infection thread. Can. J. Microbiol. 23: 573-582.

BOZZO G.G., RAGHOTHAMA K.G., PLAXTON W.C. 2002. Purification and characterization of two secreted purple acid phosphatase isozymes from phosphate-starved tomato (Lycopersicon esculentum) cell cultures. Eur. J. Biochem. 269: 6278-6286.

BUCHANAN B.B., GRUISSEM W., JONES R.L. 2000. Biochemistry and molecular biology of plants. In: Crawford N.M., 
Kahn M.L., Leustek T., Long S.R. (eds). Nitrogen and sulfur. Maryland: Am. Soc. Plant Physiol., p. 786-849.

CHAUHAN E., COWAN D.S., HALI J.L. 1991. Cytochemical localization of plasma membrane ATPase activity in plant cells. A comparison of lead and cerium-based methods. Protoplasma 165: 27-36.

CHRISTELLER J.T., TOLBERT N.E. 1978. Phosphoglycolate phosphatase. Purification and properties. J. Biol. Chem. 253: $1780-1785$.

DE LEO P., SACHER J.A. 1970. Control of ribonuclease and acid phosphatase by auxin and abscisic acid during senescence of rhoeo leaf sections. Plant Physiol. 46: 806-811.

DUFF S.M.G., LEFEBVRE D.D., PLAXTON W.C. 1989. Purification and characterization of a phosphoenolpyruvate phosphatase from Brassica nigra suspension cells. Plant Physiol. 90: 734-741.

DUFF S.M.G., PLAXTON W.C., LEFEBVRE D.D. 1991. Phosphate-starvation response in plant cells: de novo synthesis and degradation of acid phosphatase. Proc. Natl. Acad. Sci. USA 88: 9538-9542.

DUFF S.M.G., SARATH G., PLAXTON W.C. 1994. The role of acid phosphatases in plant phosphorous metabolism. Physiol. Plant. 90: 791-800.

FAHRAEUS G. 1957. The infection of clover root hairs by nodule bacteria studied by single glass slide technique. J. Gen. Microbiol. 16: 374-381.

FERREIRA C.V., TAGA E.M., AOYAMA H. 1999. Glycolytic intermediates as substrates of soybean acid phosphatase isoforms. Plant Sci. 147: 49-54.

GABARD K.A., JONES R.L. 1986. Localization of phytase and acid phosphatase isoenzymes in aleurone layers of barley. Physiol. Plant. 67: 182-192

GELLATLY K.S., MOORHEAD G.B.G., DUFF S.M.G., LEFEBVRE D.D., PLAXTON W.C. 1994. Purification and characterization of a potato tuber acid phosphatase having significant phosphotyrosine phosphatase activity. Plant Physiol. 106: 223-232.

GIBSON D.M., ULLAH A.H. 1988. Purification and characterization of phytase from cotyledons of germinating soybean seeds. Arch. Biochem. Biophys. 260: 503-513.

GOMORI G. 1950. An improved histochemical technique for acid phosphatase. Stain Tech. 25: 81-85.

GUO J., PESACRETA T.C.J. 1997. Purification and characterization of an acid phosphatase from the bulb of Allium cepa $\mathrm{L}$. var. sweet spanish. Plant Physiol. 151: 520-527.

HALL J.L., CHAUHAN E., COWAN D.S. 1992. Cytochemical localization of the plasma membrane ATPase in higher plant cells. In: Mejias-Mejias L., Rodriguez-Garcia M.I., Rios A., Arias J.M. (eds). Electron microsopy, 1992, Vol. 3. Granada: Biological Sciences, p. 219-220.

HIGASHI S., KUSHIYAMA K., ABE M. 1986. Electron microscopic observations of infection threads in driselase treated nodules of Astragalus sinicus. Can. J. Microbiol. 32: 947-952.

HULSTAER C.E., KALICHARAN D., HARDONK M.J. 1983. Cytochemical demonstration of phosphatases in the liver by cerium-based method in combination with osmium tetraoxide and potasium ferrocyanide post-fixation. Histochem. 78: 71-79.

JONES D.T., VILLIERS T.A. 1972. Changes in distribution of acid phosphatase activity during wound regeneration in $\mathrm{Co}$ leus. J. Exp. Bot. 23: 375-380.

KANELLIS A.K., SOLOMOS T., MATTOO A.K. 1989. Changes in sugar, enzymatic activities and acid phosphatase isoenzyme profiles of bananas ripened in air or stored in $2.5 \% \mathrm{O}_{2}$ with and without ethylene. Plant Physiol. 90: 251-258.

KANTZ D.B., SUSSMAN M.R., MIERZWA R.J., EVERT R.F. 1988. Cytochemical localization of ATPase activity in oat roots localizes a plasma membrane-associated soluble phosphatase, not the proton pump. Plant Physiol. 86: 841-847.
KENTON P., MUR L.A.J., DRAPER J. 1999. A requirement for calcium and protein phosphatase in the jasmonate-induced increase in tobacco leaf acid phosphatase specific activity. J. Exp. Bot. 50: 1331-1341.

LAL M., JAISWAL V.S. 1988. Modification of flower sex and acid phosphatase activity by phthalimides in female plants of Morgus nigra L. Plant Growth Regul. 7: 29-37.

LEFEBVRE D.D., DUFF S.M.G, FIFE C., JULIEN-INALSINGH C., PLAXTON W.C. 1990. Response to phosphate deprivation in Brassica nigra suspension cells. Enhancement of intracellular, cell surface and secreted phosphatase activities compared to increases in Pi-absorption rate. Plant Physiol. 93: 504-511.

MYLONA P., PAWLOWSKI K., BISSELING T. 1995. Symbiotic nitrogen fixation. Plant Cell 7: 869-885.

NEWCOMB W., MCINTYRE L. 1981. Development of root nodules of mung bean (Vigna radiata): a reinvestigation of endocytosis. Can. J. Bot. 59: 2478-2499.

OLMOS E., HELLIN E. 1997. Cytochemical localization of ATPase plasma membrane and acid phosphatase by cerium-based method in a salt-adapted cell line of Pisum sativum. J. Exp. Bot. 48: 1529-1535.

PAN S. 1987. Characterization of multiple acid phosphatases from salt stressed spinach leaves. Austr. J. Plant Physiol. 14: 117-124.

PANARA F., PASQUALINI S., ANTONIELLI M. 1990. Multiple forms of barley root acid phosphatase: purification and characterization of the major cytoplasmic isozyme. Biochim. Biophys. Acta 1037: 73-80.

PENHEITER A.R., DUFF S.M.G., SARATH G. 1997. Soybean root nodules acid phosphatase. Plant Physiol. 114: 597-604.

PLAXTON W.C., CARSWELL M.C. 1996. Metabolic aspects of the phosphate starvation response in plants. In: Lerner H.R. (ed.). Plant response to environmental stresses: From phytohormones to genome reorganization. New York: Marcel Deker, p. 349-372.

RANDAL D.D., TOLBERT N.E. 1971. 3-Phosphoglycerate phosphatase in plants. I: Isolation and characterization from sugar cane leaves. J. Biol. Chem. 246: 5510-5517.

RECORD R.D., GRIFFING L.R. 1988. Convergence of the endocytic and lysosomal pathways in soybean protoplasts. Planta 176: 425-432.

REYNOLDS E.S. 1963. The use of lead citrate a high $\mathrm{pH}$ as an electron opaque stain in electron microscopy. J. Cell Biol. 17: 208-212.

ROSSI A., PALMA M.S., LEONE F.A., BRIGLIADOR M.A. 1981. Properties of acid phosphatase from scutella of germinating maize seeds. Phytochemistry 20: 1823-1826.

SMART J.B., DILWORTH M.J., ROBSON A.D. 1984. Effect of phosphorus supply on phosphate uptake and alkaline phosphatase activity in rhizobia. Arch. Microbiol. 140: 281-286.

STASWICK P.E., PAPA C., HUANG J., RHEE Y. 1994. Purification of the major soybean leaf acid phosphatase that is increased by seed-pod removal. Plant Physiol. 104: 49-57.

TORRIANI A. 1990. From cell membrane to nucleotides: the phosphate regulon in Escherichia coli. BioEssays 12: 371-376.

TU S.I., LAVANAUGH J.R., ROSWEII R.T. 1990. Phosphate uptake by excised maize roots tips studies by in vivo ${ }^{31} \mathrm{P}$ nuclear magnetic resonance spectroscopy. Plant Physiol. 93: 778-784.

ULLAH A.H.J., GIBSON D.M. 1988. Purification and characterization of acid phosphatase from cotyledons of germinating soybean seeds. Arch. Biochem. Biophys. 260: 514-520.

VASSE J., DE BILLY F., CAMUT S., TRUCHET G. 1990. Correlation between ultrastructural of bacteroids and nitrogen fixation in alfalfa nodules. J. Bacteriol. 172: 4295-4306. 